\title{
Patients vary: so do wines
}

\author{
Shaun McCann ${ }^{1}$
}

Received: 29 January 2019 / Accepted: 29 January 2019 / Published online: 15 February 2019

(c) Springer Nature Limited 2019

"He who knows how to taste does not drink wine but savours secrets" Salvador Dalì. Spanish Surrealist. $1904-1989$.

All physicians know that there is huge variability in the way patients respond to medication. I suppose the most obvious example for haematologists is the number of patients with acute lymphocytic leukaemia (ALL) or graft versus host disease (GvHD) after hematopoietic cell transplantation (HCT) who receive very large doses of corticosteroids of which a few develop avascular necrosis or osteonecrosis of bone (AVN). Although we have known that the head of the femur is the most commonly affected bone, the humerus, knees, ankles and the jaw can also be affected. The pathobiology of AVN is a disruption of the extraosseous blood supply. AVN is characterised by a stereotypical pattern of cell death and a complex repair process of bone resorption and formation. It is not the necrosis itself but rather the resorptive component of the repair process that results in loss of structural integrity and subchondral fracture. Most likely, a common pathophysiological pathway exists involving compromised subchondral microcirculation [1]. Pain and reduced movement are early symptoms and signs and although not life-threatening AVN can cause severe distress and marked morbidity to patients with a life-threatening underlying disease. The incidence of $\mathrm{AVN}$ in patients treated with corticosteroids varies from 4-7\% and a mean daily dose $>20 \mathrm{mgs} /$ day seems to be the main risk factor. It is best diagnosed by MRI. Mary Relling from St Jude's has carried out extensive research and she and her colleagues suggest that a single nucleotide polymorphism (SNP) rs6461639 might provide a clue as to which patients treated with high dose corticosteroids are susceptible to AVN [2].

Shaun McCann

shaunrmccann@gmail.com

1 University of Dublin Trinity College, Haematology Emeritus, Dublin, Ireland
Do wines from a single vineyard, grape variety and crop differ? Yes they can. The phenomenon is known as 'bottle variation'. As the French say: 'there is no such thing as a good wine, only a good bottle'. The phenomenon of 'bottle variation' came into sharp focus for me a few weeks ago when Chiara (my wife) remarked that the Bordeaux wine we were drinking for dinner tasted quite different to the one we had the previous evening even though both wines were from the same vineyard, vintage and grape variety. A number of factors can influence the way a wine tastes. Vines in different parts of a vineyard may be planted in different types of soil (terroir in France and territorio in Italy) and have different exposure to sunlight all of which can influence the taste of the final product.The method of storage is very important. Exposure to heat or high levels of humidity may contribute to variations as well as fill levels [3]. Of course there may be subtle and as yet illdefined genetic differences in grapes from the same crop. The method of closure is also important. James Laube who writes for The Wine Spectator said in his blog on 20 November 2014 he was surprised to discover that a flaw in the wine bottle, may be the culprit. Richard Hemming MW writing for Decanter magazine in July 2018 agrees that closure with corks is very important. Corks limit exposure of the wine to oxygen and according to Jacques Lurton a noted wine maker: 'with cork it is impossible to avoid bottle variation...'. The company Corticeira Amorim, a Portuguese cork producer with over 150 years experience, is working hard to produce 'perfect' corks and thus to eliminate the cork as a cause of bottle variation. The contribution of corks to the latter should NOT be confused with 'corked wines' in which the cork is contaminated with TCA (2,4,6 - Trichloroanisole) [3]. Corticeira Amorim now guarantees their corks will have $<0.5 \mathrm{ng} / \mathrm{L}$ of TCA. Another factor contributing to the variation is sulphur dioxide $\left(\mathrm{SO}_{2}\right)$ which is used in wine making to prevent bacterial contamination. Too little $\mathrm{SO}_{2}$ increases the risk of bottle variation and too much gives wine a nasty taste! So as in medical practise experience is the key to better results [4]. 
Finally does size matter? Most wine experts agree that the bigger the bottle the lower the chance of bottle variation and as Hugh Johnson says: 'the bigger the better'. So never buy half bottles and purchase magnums if you can. Meanwhile the search for factors involved in patient responses to medication continues and hopefully bottle variation in wine will eventually cease to be a problem.

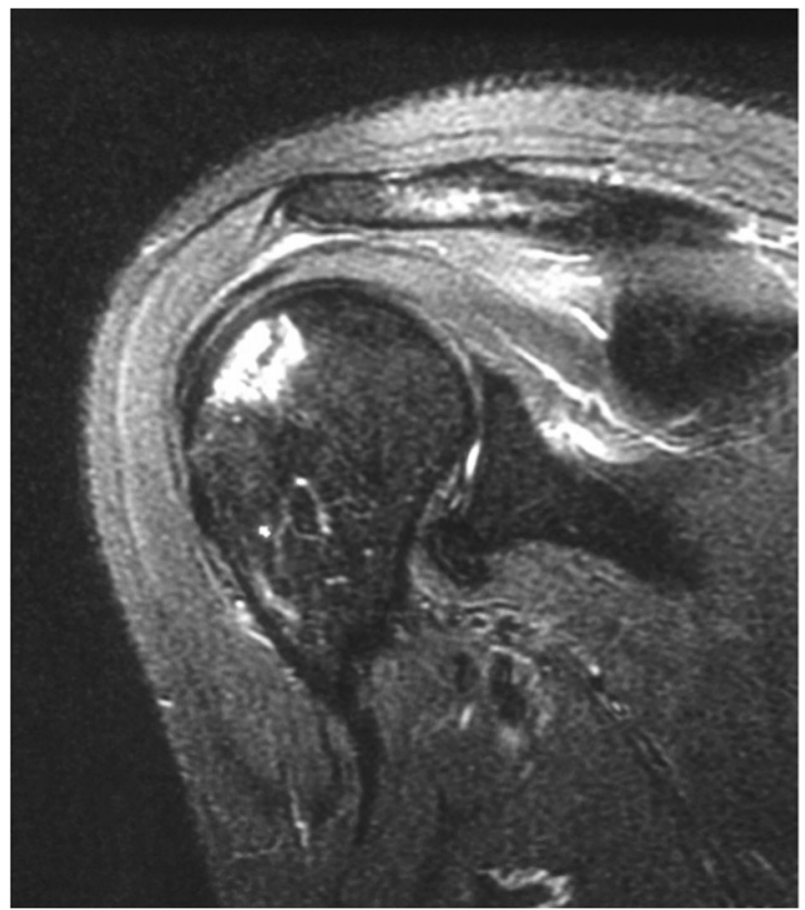

MRI of AVN. Courtesy of Dr Ronan McDermott. St James' Hospital, Dublin. MRI showing AVN of humeral head. I am grateful to Professor Owen Smith, Professor of Paediatric and Adolescent Medicine, University College Dublin, for bringing the work of Mary Relling to my attention.

\section{Compliance with ethical standards}

Conflict of interest The author declares that he has no conflict of interest.

Publisher's note: Springer Nature remains neutral with regard to jurisdictional claims in published maps and institutional affiliations.

\section{References}

1. Shah KN, Racine J, Jones LC, Aaron RK. Pathophysiology and risk factors for osteonecrosis. Curr Rev Musculoskelet Med. 2015;8 (3):201-9.

2. Park HW, Tse S, Yang W, Kelly HW, Kaste SC, Pui CH, et al. A genetic factor associated with low final bone mineral density in children after a long-term glucocorticoid treatment. Pharm J. 2017;17(2):180-5.

3. Robinson J. The Oxford Companion to Wine. 4th edition. Oxford: Oxford University Press; 2015.

4. McCann S. Microscopes and corkscrews. Bone Marrow Transplant https://doi.org/10.1038/s41405-018-0408-x 